\title{
Navigating the College Experience: The Human Faces of Refugees Students
}

\author{
Claudia Peralta ${ }^{1^{*}}$ \\ ${ }^{1}$ Boise State University, USA \\ *Correspondence: claudiaperalta@boisestate.edu
}

\begin{abstract}
As the refugee population continues to increase, the Trump administration continues to slash resettlement admissions framing refugees as a security threat. Education is a fundamental human right, and it is the best avenue for self-reliance. This paper explores how refugee students conform to, and persist schooling. Using Critical Race Theory as a framework, evidence of "sticky mess" or racial inequalities (Espinoza and Harris, 1997) was shown to impact the lives of all participants. However, the strength of community cultural wealth (Yosso, 2005) assuaged the negative didactic experiences. Analysis of the dialogic semi-structured interviews that compromised the data set focused on the refugees' lives and educational experiences in their journey to the U.S.

Keywords: refugee, higher education, community cultural wealth
\end{abstract}

\section{Introduction}

We must not believe the many, who say that free persons only ought to be educated, but we should rather believe the philosophers, who say that the educated only are free. (Epictetus, 2011, p. 51)

No country can ignore the worldwide displacement of individuals and families who are seeking a safe haven from violence that is often indiscriminate in its victims. The yearly Global Trends report (United Nations High Commissioner for Refugees, 2019) confirms an unprecedented 79.5 million people around the world have been forced to leave their homes because of persecution, conflict, violence or Received November 11, 2019; revised April 17, 2020, and September 1, 2020; accepted November 15, 2020; electronically published December 18,2020

Journal of Comparative \& International Higher Education

December, 2020, Vol. 12, No. 3, pp. 199-221.

DOI: 10.32674/jcihe.v12iWinter.3259

(c) 2020 Journal of Comparative \& International Higher Education. All rights reserved. 
human rights violations at the end of 2019. Forced displacement affects more than one percent of the humanity or one in every 97 people. 26 million of displaced persons are refugees, and over half of these refugees are under the age of 18 (United Nations High Commissioner for Refugees, 2019). Since 1975 the United States has welcomed about 3.2 million refugees. In 2016, the United States admitted 84,995 refugees, and in 2018, 22,491 were admitted, roughly half the 45,000 cap. In 2019 the number of received refugees matched the ceiling cap of 30,000. However, in 2020 only 11,841 were admitted with the annual ceiling of 18,000 - the lowest level in record (Migration Policy Institute).

The economic, political and cultural issues that accompany this crisis are complex, but from a humanitarian perspective, not attending to them is not an option. Moreover, recognizing that providing access to education is a main concern for refugee communities, the office of the United Nations High Commissioner for Refugees (UNHCR) underlines that education is not only a basic right, but an essential component of rehabilitation an "enabling right, through which other rights are realized" (DrydenPeterson, 2011, p. 9).

In 2018 three percent of the world refugee population was enrolled in tertiary education (UNHCR, 2020), and a large part of them navigate invisibly the educational system. A strong understanding of how refugee students make sense of their educational experience is a priority. Examining the experiences of refugee students who are trying to reeducate or retool themselves in a new country, or are accessing post-secondary education for the first time, is critical in meeting their needs. Access to higher education may play a pivotal role in easing transitions for refugees by affording skills that increase social capital. Social capital is defined by Bourdieu (1986) as the accrued resources acquired by belonging to a network of social relationships and/or group memberships, and are transmissible to other contexts (Marar, 2011; Taylor \& Sidhu, 2012) that a person can utilize for advancement. 
Recent literature on refugee students in school settings has focused mostly on young children or adolescents' adjustment (Dryden-Peterson, 2011; McBrien, 2005). Despite the small amount of research on young people experiences (18-24 years old) accessing higher education, studies suggest educational opportunities may cushion refugees from the negative aspects of forced migration. Refugees often experience a loss of dignity when their level of education or former position are no longer valued or recognized by the new community, which in consequence impacts their quality of life (Vries \& Van Heck, 1994). Moreover, long-term displacement brings about a sense of helplessness, leading to low selfesteem (Horn, 2010). Thus, refugees view education as a way to increase their quality of life and widen their livelihood of opportunities (Crea and McFarland, 2015; Crondahl and Karlsson, 2012). Education is also perceived as a means of personal empowerment and efficacy (Gateley, 2011). Education may help refugees develop a "critical consciousness" by providing them with a voice, thus empowering them to create change (Dryden-Peterson and Giles, 2010).

For people who have lost all their other assets, education represents a primary survival strategy. Education is the key to adaptation in the new environment of exile. Education is the basis upon which to build a livelihood. For some, education will be the decisive factor for resettlement in a second (or third), normally richer country (Flukiger-Stockton, 1996).

\section{Discussion: Questions we should ask}

The current literature on refugee students attending higher education focuses on the role education plays in their lives, while highlighting the "cultural capital" refugees lack and how this impacts their college experience (Crea, 2016; Gateley, 2015; Kanno \& Varghese, 2010; Naidoo, 2015). Bourdieu (1986) defines cultural capital as familiarity with the legitimate culture or high culture within society. While these studies bring a deeper understanding of how refugees can be academically supported, little research focuses on what refugee students bring to the college experience. 
The objective of this paper is to evaluate what we know about refugee students' experiences in higher education through the application of Yosso's Community Cultural Wealth (CCW) framework, an underutilized framework within higher education. The paper presents implications of employing this theoretical framework, and offers new insights that extend how CCW is conceptualized. Guided by these tenets, the counterstories (Solórzano \& Yosso, 2009) documented in this study responded to the following research questions:1) How did refugee students resist, conform to, and persist in their educational experiences? 2) What do these refugee students identify as useful capital, and what factors contributed to their success in navigating the educational system? It is important to point out that even though the author of this paper uses the term "refugee student", it is not intended "to reinforce their identities as singular subjectivities-victims-or to constitute them as powerless" (Ferfolja 2009, 397 as cited in Ferfolja \& Vickers 2010, 159)

\section{Theoretical Framework}

Critical Race Theory (CRT) and Yosso's (2005) notion of CCW will be utilized to understand how refugee students navigate their educational experiences in higher education. While education in modern democratic societies is believed to play a role in reducing inequalities, critical race theory educational scholars argue that critical race theory advances a strategy to account for the role and racism in education. Critical race theory challenges the belief that the educational system is objective, color blind, and provides equal opportunity for all. The transmission of inequalities occurs because children from the dominant group possess cultural capital similar to that of the educational system, and minority groups do not.

Refugees possess cultural capital but it is incongruent with the symbolic and social expectations of the school system. CRT legitimatizes the experiences of People of Color by understanding, analyzing and teaching about the subordination experiences. Critical race research views this knowledge as a strength and draws explicitly on their experiences to learn about issues of class, race, sexism, etc. In 
other words, CRT "advances a strategy to foreground and account for the role of race and racism in education and works toward the elimination of racism as part of a larger goal of opposing or eliminating other forms of subordination based on gender, class, sexual orientation, language, and national origin." (Solórzano \& Yosso, 2009, 132).

In education, CRT has been defined as a "discourse of liberation" that can be used as a methodological tool as well as a greater ontological and epistemological understanding of how race and racism affect education and lives of racially disenfranchised (Parker \& Lynn 2002, 7-8). It has also been defined as a "framework that can be used in theorizing about the ways in which educational structures, processes and discourses support and promote racial subordination" (Solórzano \& Delgado Bernal, 2010, 314-315).

Yosso (2005) expands this view by introducing CCW and shifting the research lens away from a deficit view of Community of Colors, and focusing on the array of cultural knowledge, skills, abilities and contacts possessed, and used to survive and resist the oppressions felt the macro and micro level. She asserts that CCW comprises at least six forms of capital: aspirational, linguistic, social, navigational, familial, and resistant. This study will attempt to continue Yosso's work by identifying forms of "capital" students of color (specifically refugees) possess and accumulate while they are navigating college.

Students within this study were successful in activating and utilizing linguistic and navigational capitals. In addition, the data revealed two other capitals used by the participants, which I termed: compassionate and educational community capitals.

\section{Methodology}

\section{Data source, evidence and objects}

A total of 11 participants from a metropolitan university in the Northwestern United States with little over 22,000 students took part in the study. Table 1 shows the demographic characteristics for the participants as well as their education. 


\section{Table 1}

Demographics

\begin{tabular}{|c|c|c|c|c|c|c|}
\hline Gender & Pseudonym & Nationality & $\begin{array}{l}\text { Countries } \\
\text { resided before } \\
\text { arriving to U.S. }\end{array}$ & $\begin{array}{l}\text { Education/jobs } \\
\text { prior to arriving } \\
\text { to U.S. }\end{array}$ & $\begin{array}{l}\text { Major/Fiel } \\
\text { d of study } \\
\text { in U.S. }\end{array}$ & $\begin{array}{l}\text { Date of } \\
\text { arrival } \\
\text { to U.S. }\end{array}$ \\
\hline $\mathrm{F}$ & BB & Bosnian & Germany & $\begin{array}{c}\text { Student: Middle } \\
\text { School }\end{array}$ & Education & 2000 \\
\hline $\mathrm{F}$ & RM & $\begin{array}{c}\text { Afghanista } \\
\mathrm{n}\end{array}$ & Pakistan & $\begin{array}{l}\text { Student: High } \\
\text { School } \\
\text { (Graduated) }\end{array}$ & $\begin{array}{l}\text { Health } \\
\text { Science } \\
\text { and } \\
\text { Respiratory } \\
\text { Care }\end{array}$ & 2007 \\
\hline M & NMM & $\begin{array}{c}\text { Afghanista } \\
n\end{array}$ & $\begin{array}{l}\text { Pakistan } \\
\text { Russia }\end{array}$ & $\begin{array}{c}\text { Student: } \\
\text { University } \\
\text { (Engineering) } \\
\text { B.A. }\end{array}$ & $\begin{array}{c}\text { Engineerin } \\
\mathrm{g}\end{array}$ & 2008 \\
\hline$M$ & DN & Eritrea & $\begin{array}{l}\text { Ethiopia } \\
\text { refugee camp } \\
\text { (6 yrs.) }\end{array}$ & $\begin{array}{c}\text { Teacher: Junior } \\
\text { High } \\
\text { Subjects: Math \& } \\
\text { English }\end{array}$ & $\begin{array}{l}\text { Computer } \\
\text { Science }\end{array}$ & 2012 \\
\hline M & MA & Iraq & & $\begin{array}{c}\text { Student: } \\
\text { University } \\
\text { (Engineering for } \\
1 \mathrm{yr} \text {.) }\end{array}$ & Engineer & 2012 \\
\hline & & & & Student: High & & \\
\hline M & LA & Iraq & Syria & $\begin{array}{c}\text { School } \\
\text { (Graduated) }\end{array}$ & Engineer & 2009 \\
\hline M & $\mathrm{FF}$ & Iran & Turkey & $\begin{array}{l}\text { Student: } \\
\text { Photoshop } \\
\text { Certificate }\end{array}$ & Journalism & 2011 \\
\hline M & AA & Iraq & & $\begin{array}{l}\text { Student: College } \\
\text { (English \& Art } \\
\text { Major) } \\
\text { U.S. Interpreter: } \\
\text { of English }\end{array}$ & $\begin{array}{c}\text { Biochemist } \\
\text { ry }\end{array}$ & 2012 \\
\hline M & DS & Bhutan & $\begin{array}{l}\text { Nepal refugee } \\
\text { camp (17 yrs.) }\end{array}$ & $\begin{array}{l}\text { Student: College } \\
\text { (Computer } \\
\text { Science in Nepal) }\end{array}$ & $\begin{array}{l}\text { Computer } \\
\text { Science }\end{array}$ & 2008 \\
\hline M & DM & Congo & & $\begin{array}{c}\text { B.A. } \\
\text { Teacher: (High } \\
\text { School) } \\
\text { Subject: French }\end{array}$ & $\begin{array}{l}\text { Political } \\
\text { Science } \\
\text { and } \\
\text { Internation } \\
\text { al Relation }\end{array}$ & 2012 \\
\hline M & $\mathrm{KA}$ & Congo & $\begin{array}{l}\text { Botswana } \\
\text { refugee camp } \\
(2 \text { yrs. })\end{array}$ & B.A. & MBA & 2007 \\
\hline
\end{tabular}


The university where the research was conducted does not have a way to identify refugee students, thus participants were recruited. Recruitment was done at intensive writing English classes at the university, at the local refugee conferences and community coordination meetings. After an initial verbal invitation to participate in the study the participants were formally invited via email or phone. Once participants agreed to be part of the study, they were interviewed.

All of the students participated in semi-structured interviews that lasted approximately 90 minutes (See Appendix A). The interviews were conducted at a time and place convenient to the participants and English was used as the main language. Interviews were transcribed fully, and qualitatively analyzed.

After reflecting on the data, I coded the transcripts and organized them into thematic "chunks" (Rossman \& Rallis, 1998). While analyzing the data, I became aware of the ways students responded to their experiences in higher education by drawing on hidden funds of knowledge (Martínez-Roldán \& Fránquiz, 2008) present in their peers and communities. As I created common categories across transcriptions of the audio recordings, I found that the categories aligned well with Yosso's (2005) forms of community cultural capital as reflected in her CCW framework. The findings reported in this article advance Yosso's (2005) framework by illuminating how participants cultivated two new forms of cultural capital to move beyond oppressive structures in order to achieve positive educational outcomes. In the presentation of the findings I describe the CCW framework as explained by Yosso (2005). Second, I share examples from the data to demonstrate how the CCW framework provides an explanatory theory for interpreting the counter narratives voiced by the students. Additionally, the two forms of cultural capital identified in the data: Compassionate Capital and Community Capital are introduced. These two new cultural capitals extend the CCW framework. 


\section{Findings}

The interviews demonstrated the resiliency of the students despite negative racial experiences. Specifically, language, culture, immigration status, and race inferences received. This played a role on how the students navigated the college experience and how they confronted and resisted the barriers faced along the way. I decided to use initials for all proper nouns instead of given them pseudonyms in order to respect their birth names.

\section{Linguistic Capital}

Linguistic capital is defined by Yosso (2005) as the intellectual and social skills learned through communication experiences in more than one language and/or style. The majority of the participants arrived in the U.S. knowing at least two languages. Even though the participants knew more than one language, they had on average an intermediate proficiency in English, and were academically proficient in their first language. Hence, language was one of the biggest issues in their education. The main problem was being understood by others, and understanding the professors. One of the participants shared, "Even though I was an English teacher in Eritrea, I am struggling with English because most of the time I can't understand what they [professors] are saying to me and sometimes they [other students] never understand what I am saying. Sometimes the pronunciation is hard to understand" DN. MA contributed by saying, "Language is hard. You have a counselor who helps you pick the classes but that is all. They do not help you as a refugee student. They do not care. Professors are not aware what it means to learn a new language." DN further elaborated about the difficulty understanding the instructor's response when requesting clarification because the professors do not get what he is asking and they do not give him the right response.

A layer identified to the language barrier was written language in relation to time. LA frustration about this was noticeable when he commented, "I knew the answers to the questions [in the test] but I run out of time and even though I requested a time extension the professor's response was, 'you have 
to learn more English and [then] come back [to the University]'." He added: "Every class [content] is a new language, and they [professors] don't really care about you [us]." FF echoed this sentiment by declaring,

You know, the biology [class] is truly my nightmare [every] Thursday night. Thursday nights I have a dream about tomorrow's quiz. It's painful. It's really painful. I'm the only non-American person in the class. The lecture has 150 to 200 people.

Even though FF felt exasperated, he questioned the underlying cultural norms that privilege native speakers' linguistic capital and ignore the language learners' multilingual competence. FF asked permission to use Google translate from his phone but this option was denied. The instructor suggested a dictionary instead. FF defended his request by explaining that using his phone to access Google translate was easier and faster for him than using a hard copy dictionary. Unfortunately, he was not informed by the professor he could instead use an electronic translator, a tool allowed and listed in the testing policies and procedures of the University. FF reflected on the fact that even though time was important for the professor, using a dictionary would slow him down even more, thus further affecting his score. He expounded that the quiz was designed to evaluate content knowledge, not his English language proficiency, hence allowing him to use the Google translate would simply aid him in demonstrating his knowledge of the content. Events like this brought about resentment that contributed to 'resisting' the course, and the professor. Unfortunately, FF became so enraged that he dropped the class.

Reflecting on the stories, it is evident that the instructors of the courses did not view students' bilingualism as an asset or bother to utilize the language and communication strengths of the students. On the contrary, the fact that they were bilinguals was viewed as a problem. Moreover, it was viewed as a students' problem. Thus, all of the responsibility and blame falls on the student without understanding students' success is a collective effort involving educators. 


\section{Navigational capital}

Navigational capital refers to students' skills and abilities to navigate "social institutions," including educational spaces. Yosso (2005) further explains students' navigational capital empowers them to maneuver within unsupportive or hostile environments. Students experienced difficulty understanding and navigating the unfamiliar and complex educational system of the University.

Misunderstanding about the courses they needed to take was as a source of confusion and frustration. After FF dropped the biology course, he kept wondering how this would impact his GPA but understood that he just could not keep on guessing; he needed to be informed. He reached out to one of his friends, and then his advisor. This is what he shared,

[I talked to] one of my people, he is a refugee, but he came here ten years ago, he's an Iranian student. And, then [I talked] to my advisor...she told me that it is not harmful to withdraw Biology, [because] it is not part of my requirements.

However, FF research did not stop there, at one of the refugee alliance meetings he asked the guest speaker the impact of dropping a class and learned students can drop a class as many as four times before receiving the grade letter $\mathrm{F}$.

Lack of familiarity with the technology platform used by the University was another source of confusion and stress. One of the participants revealed, "I was in class for four weeks before I figure out Blackboard was a site where you could look up the syllabus and professors' notes." He clearly remembers having a professor say, "ok, open up Blackboard" and feeling inadequate because he did not know what it was. Eventually, he asked his advisor and the response he received was "How can you not know [about Blackboard]?"

The U.S. teaching approach was noted as another point of struggle. An example of this is what a refugee 'heard' the professor said about the assigned textbook "you will read Chapter five and eight." He was shocked, he did not understand why one would start reading in the middle of a book. So, he did 
not follow the instructor's instructions and started on Chapter one because, as he pointed out, "in my country we start [a book] in the beginning." And the next day he heard his professor said: "OK, the three chapters you read for today will be in the exam. Be ready!" At that moment, he realized he was way behind schedule.

It is evident students understood that 'navigating' the system meant disabling 'hidden' educational devices that weaken or negatively impacted their educational success. Reaching out to more knowledgeable peers and assigned educational counselors aided them in understanding how to cope with invisible mechanism. Furthermore, at times, they triangulated the responses evaluating the best plan of action.

\section{Compassionate Capital}

The word 'compassion' is derived from the Latin cum patior, meaning 'to suffer, undergo, and stand in solidarity with others' (Straub, 2000) or as defined by Chodron (2001), 'our ability to feel the pain that we share with others' (4). According to the Dalai Lama (2001), "one thing very specific to the contemplation of suffering is that it tends to be more powerful and effective if we focus on our own suffering and then extend that recognition to the suffering of others" (p. 93).

In the interviews, participants shared their experiences of exclusion, pain and suffering while trying to navigate the educational system. However, the refugees' educational experiences inspired them to help others. DS made it clear that when his friends from the community have questions about education, he helps them. He noted, "I am a senior here and now I know how education works. No one tells you to get an education, the refugee agencies don't push for education, so it is now my responsibility [emphasis]."

BB was in the wave of Bosnian's who left in 1993 and arrived to the U.S. as a refugee in 2000. She is an only daughter and became the language broker for her parents. The fact she has native like proficiency in German, Bosnian, Croatian, Serbian and English lead her to become the language broker 
for the Bosnian community. Being the language broker gave her access to the stories of what happened to the refugees during the war, which inspired her to become a role model and advocate for the next generations of refugees. "Every time, I see myself in them [refugees]. First it was us [the Bosnians], then the Middle Eastern, then the Sudanese, now the Nepalese, so you can see the sequence." She shared how painful it was to scape during a winter night, to say goodbye to her father and to leave behind "her childhood." She talked about the "terrible things" that happened to the refugees and how pursuing a doctoral degree will afford her the opportunity to support refugee college students by creating spaces to share their experiences. BB was also inspired to co-found the Student Refugee Alliance (SRA). She visits high school with high representation of refugee students describing the process of securing admission to college, and introducing them to professionals who can help them plan appropriately for college costs. She further shares "Maybe I want to be the role model to tell the younger generation or even generations my age or, maybe older generations like my husband, that you can go to school. I did it and you can do it too."

Another participant, DM, reflected on his first eight months of his life in the U.S. He commented that distances were enormous and every time he wanted to go somewhere, he simply had to resign to wait for the bus, he could not just go to the supermarket when he needed something. Today, he takes refugees to the supermarket and hospital or anywhere else they may need to go, because he remembers what it was like. He recalled how hard it is for new arrivals to go to the bank and understand the documents they sign. In his words "we need to help others. People helped me before, so now I have the [educational] means, I need to help others who need help." He continued by saying "if they do not know how to apply for school, I help them, if someone's car has broken down, I get a call. I got to help them." He wants to pursue a career that helps ladies and children become stable. A testament to his commitment is his 'sharing' of his wealth. Last year he bought four pairs of shoes for "those refugees who needed them." He understands what it feels to have little and to need support. He shared that 
when escaping his country, he spent four days without food, not because he did not have money, but because there was no place to buy anything. He saw his friend's children die of hunger. He understands empathy, feeling someone else's pain. He has learned not to throw away food, and in a very commanding yet soft tone he said "we must learn and teach other how to prepare only [the food] we can eat. . . we cannot waste food."

The opportunity for education also provided the space and abilities to support the ones left behind. FF uses blogs to reach out to 'another world, to participate in their experiences' to understand their situation. One of his blogs is in English and the other in Persian. One focuses on human rights issues in Iran-through his religious lens. The other is a diary of what happened to him from the moment he left Iran. He has documented every step of his journey because he wants to help others going through the same experience. He wants Iranians who need to leave Iran to know about 'the process.' He recalled how difficult was to apply for refugee status because every time he inquired; he received a different response. Now, he "is helping the ones left behind." He also wrote about what it felt leaving Iran and what is like in the U.S. The recognition he received after producing a film in the Learning Service class-and the opportunity to be awarded the "People's Choice" by the class-fueled his confidence to pursue communication as his major. Undoubtedly, education has given FF the courage to reflect on the power of words and on the power of education.

He is adamantly committed to help make education a priority for all refugees. He understands the relationship between education and power so when a group of students were interviewing a director of a refugee center, he questioned why education was not ever mentioned to refugees when they arrived to the U.S. and why refugees were always pushed to find work as soon as possible. He continued by questioning the director why only eight months were allotted to find a job before the financial support ends and why, if education is chosen instead of a job, the financial support stops. 
All of these stories provide a background of how education moved these refugees beyond empathy to help them stand in solidarity with other refugees. The opportunity to share their stories gave them voice. Helping refugees being heard has become a community goal.

\section{Educational Community Capital}

Refugees' experiences of personal growth also inspired participants to rethink the way they related with the members of their ethnic communities. Some participants shared during the interview that when applying for refugee status, they hidden the fact they had relatives in the U.S. These students believed that living away from their countrymen would give them the advantage of adjusting faster to the culture and the language of the host country. LA said: "I didn't want to bother my relatives and also I wanted to learn English." Another participant eloquently explained his reasoning,

I just wanted to be away from the Iranian community, because if I just started [living] in a city without them I would work with Americans, study with Americans and live with Americans. I would learn the American culture. I wanted to adapt as soon as possible.

Other participants decided not to 'mingle' or become friends with other students who shared their same ethnic background. AH said, "I talk to other students from Saudi Arabia, Egypt, China or any other country except Iraq to find out what classes I should take." He shared such mistrust was based on his experience working as translator for the U.S. military because he did not know how others would perceive him. However, as these refugees began inserting themselves in the university culture, they understood the importance of relying on their "own people' to navigate the educational system. FF reflects when withdrawing from the Biology class, he sought his Iranian friend who had been in the U.S. for ten years for advice.

Throughout their interviews they shared how achieving the dream of "studying in America," was the benefit of the whole community. As they spent more and more time in school, they realized their adaptation, and productivity would have long-term socio-economic implications for their entire refugee 
community. It was not just a personal gain, but it was the gained of all and learning how to navigate the educational system was a community effort.

\section{Lessons Learned}

Findings suggest that despite the unsupportive educational environment, refugees are learning how to use their cultural wealth. Moreover, their unique experiences as refugees gained them access to two new capitals, compassionate and educational community. These capitals provided them the strength to navigate the educational experience while understanding their role as newcomers and what it means to belong to a larger global group of people who have left their home not by choice.

Since the time this data was collected and analyzed, the three executive orders signed in January 2019 (Center for Migration Studies, 2020) by the $45^{\text {th }}$ President of the United States, Donald Trump, have not only sent shockwaves through the vulnerable immigrant communities across the country, but to the thousands of educators who cherished and valued all community members. More than ever, it is important to equip educators and education leaders who are working closely with students who are touch by the repercussion of the executive orders to understand these students, most of all, want to succeed academically. As FF so eloquently shared when talking about education, "I don't know if you can feel my feelings but, just imagine you are a bird in a cage and they open the cage [the right to education] and you are FREE." Or as MB explained, "Going to school for myself [means] just to understand the world better."

The University where the study was conducted adopted the position that, once refugees became permanent residents or citizens, they had the same entitlements and would be treated as all other students. No attempt was therefore made to identify their special strengths. While this position may have some merit, it also results in the absence of any acknowledgement of how to best support their needs. In the words of one Iranian refugee "they ignore our needs and they treat as international students." 
During interviews, it was commonly stated that the ignorance and insensitivity of the academic staff was a major problem for them. Even though, the institution in this study has a specific center dedicated to support faculty, no specific resources such as cultural and ethnic issues are offered. Some seminars are offered throughout the academic year, but there is not required participation. Additionally, the panelists are rarely representatives of the refugee experience. Furthermore, during the annual Refugee Conference organized by community agencies and the university, local refugee students are seldom invited as keynote speakers. Even though the university is located in a welcoming refugee city, little effort has been made to integrate the refugee students into the culture of the institution. The approach so far has been not to do anything unless an issue arises which often falls on the refugee students' shoulders.

In view of the increasingly multiethnic background of the student population, and the increasing priority of Universities in attracting international students, it would seem appropriate to turn more attention to raising the cultural and ethnic awareness and sensitivity of academic staff by utilizing the strengths refugees bring. The world is facing the largest migrant crisis in human history, more than 79.5 million people-almost one percent of the world's population are displaced because of conflict. The United Nations estimates that 34 percent of eligible youth are enrolled in tertiary degree programs, yet only two percent of displaced persons have access to higher education.

The private sector recognizes the human and economic capital lost for not engaging refugees. Several private sector companies understand the opportunities associated with the diverse skills and perspectives of refugees, many having deep knowledge of the foreign market and consumer demands (Hachigian, 2016). Thus, in an effort to create bridges between the private and local communities, some companies have created mentorship programs, established financial services, and developed innovative products that meet the needs of refugees. However, Hachigian (2016) argues that scaling innovative and successful programs will not be possible until many more investors focus on migrants. She refers to 
"Migrant lens investing" as a possible solution to enhance traditional investments. "Migrant lens investing" is adopting a "migrant lens analysis" -a process- that incorporates migrant issues into responsible investment. Adopting a migrant lens could for example translate to investing in migrantowned business, which are often innovative and have a high export potential consequently benefiting the investor and migrants. This type of solution has been adopted in Canada, and Europe by lending programs that wish to support newcomer entrepreneurs. Cities have a powerful function in that they create citizens "who can imagine themselves as members of a political and economic community" (Waters \& Leblanc 2005, p. 129).

Some schools also understand the potential of the refugee population. Examples of this are Columbia University launching in 2016 the Columbia Scholarship Program for Displaced Persons, Illinois Institute of Technology and Monmouth College. Universities are creators, repositories and disseminators of knowledge, and are a strong resource for a country. University education is considered an absolute necessity for social and economic mobility and on a societal level for intellectual development of human capital. As graduates enter the work force, they often become leaders, innovators and creators generating productivity, which benefits the larger community as well as them personally.

I would propose that just as financers understands the eminence investing and helping migrants achieved their potential, education should too. Adopting a migrant education lens would mean educators and education leaders would tap into the wealth of the capitals refugees bring with them into the educational system using and integrating them into the curriculum to help others.

A recommendation would be to prepare faculty to work with linguistically and culturally diverse students. Just as in the state of California, all educators graduate with a Cross-Cultural and Language Academic Development (CLAD) certificate, professors should be required to obtain one. Or as FF recommended for the biology course, "I think it's better to have something like a cross cultural biology 
on campus because we have a lot of, you know, international and refugees [students] here in campus. So, if we have a cross cultural biology, I think it would really help us."

\section{Author Note}

Claudia Peralta is a Professor in the Department of Literacy, Language and Culture at Boise State University. Her research interests focus on multilingual education, literacy and multiliteracy, multicultural education and social justice. She has published several articles in international journals on critical issues in multilingual education, specifically on the relations between home, community and school. Dr. Peralta has documented the experiences of Mexican immigrants and first-generation Mexican youth and refugee students in the educational system in the U.S. She also co-produced two documentaries: Latino Community in Treasure Valley Idaho, and Starting Over Again: The Refugee Experience in Boise, Idaho. In 2014 she published the manual Film and Education: Capturing Bilingual Communities. Dr. Peralta serves as editor for the bi/multilingual department in Reading Teacher, in the Editorial Board for the Bilingual Research Journal, and is an Editorial Advisory Board Member for NABE Journal of Research and Practice.

\section{References}

Bourdieu, P. (1986). The forms of capital. In J. G. Richardson (Ed.) Handbook of theory and research for the sociology of education (pp. 241-258). Greenwood Press.

Center for Migration Studies (2020). President Trump executive orders on immigration and refugees. https://cmsny.org/trumps-executive-orders-immigration-refugees/ 
Chodron, P. (2001). The places that scare you: a guide to fearlessness in difficult times. Shambhala Publications.

Crea, T. (2016). Refugee higher education: Contextual challenges and implications for program design, delivery, and accompaniment. International Journal of Educational Development, 46, 12-31.

Crea, T., \& McFarland, M. (2015). Higher education for refugees: Lessons from a 4-year pilot project. International Review of Education, 61(2), 235-245.

Crondahl, K., \& Karlsson, E. L. (2012). Perceptions on health, well-being, and quality of life of Balkan Roma adolescents in West Sweden. Roman Studies, 22(2), 153-173.

Dalai Lama (2001). An open heart: practicing compassion in everyday life. Little, Brown and Company.

Dryden-Peterson, S. (2011). Refugee education: A global review. UNHCR. https://www.unhcr.org/uk/search?query=Refugee\%20Education:\%20A\%20Global\%20Review

Dryden-Peterson, S., \& Giles, W. (2010). Introduction. Higher education for refugees. Refugee, 27(2), 310.

Epictetus, C. G. (2011). The discourse of Epictetus. Greenbook Publications.

Espinoza, L., \& Harris, A. (1997). Afterword: Embracing the tar-baby: LatCrit theory and the sticky mess of race. California Law Review, 10(1), 499-559.

Ferfolja, T., \& Vickers, M. (2010). Supporting refugee students in school education in Greater Western Sydney. Critical Studies in Education, 51(2), 149-162.

Flukiger-Stockton, I. (1996). Editorial. Refugee Participation Network, 21, 3. Refugee Studies Programme.

Gateley, D. (2015). A policy of vulnerability or agency? Refugee young people's opportunities in accessing further and higher education in the UK. Compare: A Journal of Comparative and International Education, 45(1), 26-46. 
Hachigian, H. (2016). Investing in global refugee and migrant integration. Stanford Social Innovation Review. Informing and inspiring leaders of social change. https://ssir.org/articles/entry/investing_in_global_refugee_and_migrant_integration

Horn, R. (2010). Exploring the impact of displacement and encampment on domestic violence in Kakuma refugee camp. Journal of Refugee Studies, 23(3), 356-376.

Kanno, Y., \& Varghese, M. (2010). Immigrant and refugee ESL students' challenges to accessing fouryear college education: From language policy to education policy. Journal of Language, Identity, and Education, 9, 310-328.

Marar, M. M. (2011). I know there is no justice: Palestinian perceptions of higher education in Jordan. Intercultural Education, 22(2), 177-190.

Martínez-Roldán, C. and Fránquiz, M. (2008). Latina/o youth literacy. In L. Christenbury, R. Bomer, \& P.Smagorinsky (Eds.), Handbook of Adolescent Literacy Research (pp. 323-342). Guilford Press.

Migration Policy Institute. U.S. (n.d.), Annual refugee resettlement ceilings and number of admitted, refugees, fiscal years1980 through 2020. https://www.migrationpolicy.org/programs/datahub/charts/us-annual-refugee-resettlement-ceilings-and-number-refugees-admitted-united

McBrien, J. L. (2005). Educational needs and barriers for refugee students in the United States: A review of the literature. Review of Educational Research, 75(3), 329-364.

Naidoo, L. (2015). Education refugee-background students in Australian schools and universities. Intercultural Education, 26(3), 210-217.

Parker, L., \& Lynn, M. (2002). What's race got to do with it? Critical race theory's conflicts with and connection to qualitative research methodology and epistemology. Qualitative Inquiry, 8(1), 716.

Rossman, G., \& Rallis, S. (1998). Learning in the Field: An Introduction to Qualitative Research. Sage. 
Solórzano, D., \& Delgado Bernal, D. (2010). Examining transformational resistance through a critical race and LatCrit theory framework: Chicana and Chicano students in an urban context. Urban Education, 36(3), 308-342.

Solórzano, D., \& Yosso, T. (2009). Critical race methodology: Counter-Storytelling as an analytical framework for educational research. In E. Taylor, D. Gillborn and G. Ladson-Billings (Eds.), Foundations of Critical Race Theory in Education (pp.131-147). Routledge.

Straub, G. (2000). The Rhythm of Compassion. Turtle Publishing.

Taylor, S., \& Sidhu R., K. (2012). Supporting refugee students in schools: What constitutes and inclusive education. International Journal Inclusive Education, 16(1), 39-56.

United Nations High Commissioner for Refugees (2016). With 1 human in every 113 affected, forced displacement hits record high. http://www.unhcr.org/uk/news/press/2016/6/5763ace54/1human-113-affected-forced-displacement-hits-record-high.html

United Nations High Commissioner for Refugees. (2019). Global Trends. Forced displacements in 2019. https://www.unhcr.org/globaltrends2019/

USA for United Nations High Commissioner for Refugees (2020). UNHCR urges more support for refugees higher education to withstand impact of COVID-19 pandemic. https://www.unhcr.org/news/briefing/2020/9/5f72ea274/unhcr-urges-support-refugee-highereducation-withstand-impact-covid-19.html

U.S Department of State. (n.d.). Refugee Admissions. https://www.state.gov/refugee-admissions/

Vries, J., \& Van Heck, G. (1994). Quality of life and refugees. International Journal of Mental Health, 2(3), $57-75$.

Waters, T., \& LeBlanc, K. (2005). Refugees and education: Mass public schooling without a nation-state. Comparative Education Review, 49(2), 129-147. 
Yosso, T. (2005). Whose culture has capital? A critical race theory discussion of community cultural wealth. Race, Ethnicity and Education, 8(1), 69-91. 


\section{Appendix A}

\section{Interview Questions}

-Interviewee name

-Can you tell me about yourself?

-Where are you from?

-Can you share your experience living in your country, and/or a refugee camp? (Dates, places.)

-How is your community life in the U.S?

-What supports were you provided when arriving to XXX?

-What were some of the challenges you encountered in the community of XXX?

-Can you describe your educational experiences in your own country, and or refugee camp?

-Can you describe your educational experiences in the U.S.? OR

-What are your educational goals here in the U.S.?

-What were some of the educational challenges you encountered in the U.S?

-Can you describe the role your family/friends/local agencies played during your educational experience?

-Can you describe the role school members played during your educational experience here in U.S.? 